Jurnal KIBASP (Kajian Bahasa, Sastra dan Pengajaran)

Volume 1, Nomor 2, Juni 2018

e-ISSN : 2597-5218

p-ISSN : 2597-520X

DOI: https://doi.org/10.31539/kibasp.v1i2.193

\title{
GERAKAN LITERASI DALAM PEMBELAJARAN BAHASA INDONESIA BERBASIS KEARIFAN LOKAL MENUJU SISWA BERKARAKTER
}

\author{
Aceng Joyo \\ Guru dan Mahasiswa S-3 Pendidikan Bahasa Indonesia \\ Fakultas Keguruan Ilmu Pendidikan Universitas Bengkulu \\ aceng_joyo@yahoo.com
}

Submit, 26-04-2018 Accepted, 13-06-2018 Publish, 14-06-2018

\begin{abstract}
ABSTRAK
Tujuan penulisan adalah mendeskripsikan gerakan literasi dalam pembelajaran bahasa Indonesia berbasis kearifan lokal menuju siswa berkarakter dengan memanfaatkan teks yang dekat dengan lingkungan siswa. Metode penelitian berbasis masalah dan kajian literasi pustaka. Hasil penelitian menunjukkan bahwa gerakan literasi dalam pembelajaran bahasa Indonesia dapat dikaitkan dengan kearifan lokal mengingat nilainilai yang berlaku pada masyarakat belum sepenuhnya dipahami oleh siswa. Pengembangan nilai karakter siswa dalam mata pelajaran bahasa Indonesia dilakukan melalui pembelajaran keterampilan berbahasa, yaitu keterampilan menulis dan membaca. Sesuai dengan tujuan pembelajaran bahasa Indonesia, yaitu mengembangkan kompetensi siswa dalam penggunaan bahasa Indonesia sesuai dengan konteks kehidupan siswa. Pemanfaatan sumber belajar berbasis kearifan lokal akan mempengaruhi hasil dan nilai-nilai karakter. Pemanfaatan teks-teks hasil observasi lingkuangan yang ada didekat siswa akan mempengaruhi gerakan literasi menulis dan membaca.
\end{abstract}

Kata Kunci: Literasi, Kearifan Lokal, Karakter.

\section{ABSTRACT}

The purpose of writing is to describe the movement of literacy in Indonesian language learning based on local wisdom towards students characterized by using text close to the student environment. Problem-based research method and literature literature review. The result of the research shows that literacy movement in Indonesian language learning can be related to local wisdom considering that the values prevailing in society are not fully understood by the students. The development of students' character values in Indonesian language subjects is done through learning language skills, namely writing and reading skills. In accordance with the purpose of learning Indonesian, which is to develop students' competence in the use of Indonesian language in accordance with the context of student life. The utilization of learning resources based on local wisdom will affect the results and values of the characters. Utilization of the texts of the observation of the existing environment near the students will affect the literacy movement of writing and reading.

Keywords: Literacy, Local Wisdom, Character 


\section{PENDAHULUAN}

Saat ini menyosialisasikan dan meningkatkan kemampuan gerakan literasi di sekolah belum begitu membuahkan hasil yang maksimal karena masih rendahnya pendampingan dan pelatihan untuk meningkatkan kesadaran dan kemampuan literasi di kalangan siswa dan guru. Masih banyak guru yang beranggapan bahwa literasi menjadi tanggungjawab guru mata pelajaran bahasa Indonesia. Selain itu, bahan bacaan dan teks yang tersedia di sekolah belum dimanfaatkan secara optimal untuk mengembangkan kemampuan literasi siswa. Hasilnya gerakan literasi yang dicanangkan di sekolah tidak dapat terlaksana dengan baik.

Penumbuhan minat baca melalui kegiatan 15 menit membaca sesuai Permendikbud No 23 tahun 2015 bukan tujuan akhir. Guru harus memahami bahwa upaya pengembangan literasi tidak berhenti ketika siswa dapat membaca dengan lancar dan memiliki minat baca yang baik sebagai hasil dari pembiasaan budaya literasi. Pengembangan literasi perlu terjadi pada pembelajaran di semua mata pelajaran untuk mengoptimalkan kemampuan berpikir tingkat tinggi.

Para guru perlu melakukan strategi literasi dalam pembelajaran. Pengembangan kemampuan literasi di sekolah akan membantu meningkatkan kemampuan belajar siswa. Penggunaan teks dan/atau bahan ajar yang bervariasi, disertai dengan perencanaan yang baik dalam kegiatan pembelajaran diharapkan dapat meningkatkan kemampuan literasi siswa. Salah satu strategi yang dapat dilakukan sekolah adalah literasi pembelajaran berbasis kearifan lokal. Berdasarkan realitas ini maka sekolah dapat melakukan upaya penguatan pendidikan karakter melalui strategi literasi berbasis muatan lokal. Hal ini dilakukan untuk membangun kepribadian, mentalitas, moralitas yang adiluhung. Ini mengandung arti bahwa muatan lokal dapat membekali siswa untuk menjadi pribadi yang bernilai tinggi karena kebaikan budi pekertinya. Pengenalan akan kearifan lokal diharapkan dapat menjadi kekuatan budaya literasi siswa sehingga tidak mudah terpengaruh oleh budaya asing yang saat ini mudah diakses oleh siswa.

\section{METODE PENELITIAN}

Metode penelitian yang diterapkan dalam penulisan ilmiah ini adalah dengan menggunakan metode deskriptif kualitatif dari hasil pengalaman pembelajaran di kelas 
dan studi pustaka dari berbagai sumber. Teknik analisis data menggunakan analisis deksipsi berdasarkan pengamatan proses belajar mengajar yang berlangsung. Teknik pengumpulan data menggunakan observasi, dokumen pembelajaran dan hasil survei kepada siswa dan guru di sekolah. Teknik analisis data dilakukan dengan reduksi data, penyajian data dan verifikasi data sampai penarikan simpulan (Sugiyono, 2010). Penelitian ini dilaksanakan di sekolah khususnya di SMK Negeri 1 Seluma, oleh sebab itu sebagai bentuk pertanggungjawaban penelitian.

\section{HASIL PENELITIAN}

Membaca merupakan merupakan keterampilan berbahasa dan faktor yang penting dalam proses pembelajaran, karena dengan membaca peserta didik dapat memperoleh informasi. Membaca merupakan salah satu kegiatan dalam berliterasi. Literasi tidak dapat dipisahkan dari dunia pendidikan. Literasi menjadi sarana peserta didik dalam mengenal, memahami, dan menerapkan ilmu yang didapatkannya di bangku sekolah. Sebagai bentuk dukungan penulis sbegai pendidik di sekolah terhadap gerakan literasi dalam pembelajaran bahasa Indonesia maka, penulis menerapkan teksteks berbasis kearian lokal daerah. Dimana pada berdasarkan pengalaman mengajar peneliti dilapangan, siswa lebih disajikan teks-teks nasional. Akan tetapi teks tersebut terlalu jauh dari pengalaman siswa sehingga akan mempengaruhi daya kecintaan ataupun kesukaan terhadap teks.

Pada materi menyusun dan menganalisis teks kebahasaan laporan observasi, penulis memeberikan contoh sekaligus memberikan contoh kepada siswa untuk melakukan kegiatan literasi sederahana mulai dari ketarmpilan mengamati keindahan alam ataupun lingkungan yang ada di provinsi Bengkulu. Misalnya keindahan Pantai Panjang, Panorama Pantai Zakat, Pantai pasir putih ataupun keindahan benteng Malabrough. Selanjutnya peneliti menugaskan siswa untuk membaca teks yang mereka susun dan siswa yang lain.

Dengan penyusunan teks hasil obsrvasi tersebut akan menjadikan pembelajaran menyenangkan dan mengesankan bagi siswa sebagai bentuk peduli akan daerah atau bentuk kearifan lokal dimana siswa bertanggung jawab dan kerjasama dalam megerjakan tugas yang diberikan. Hal tersebut adalah gambaran pendidikan karakter 
secara tidak langsung. Berikut teks hasil observasi siswa yang bisa dijadikan sebagai teks liteasi menulis dan membaca:

\section{Contoh Teks 1 \\ Pantai Panjang yang Indah}

Indonesia memang tidak kalah cantiknya dengan negara-negara lain yang ada di luar negeri, terutama dalam keindahan pantainya. Indonesia yang diapit dua samudera yaitu samudera Hindia dan samudera Pasifik memberikan keindahan tersendiri bagi setiap pantai yang berbatasan dengan daerah-daerah di Indonesia. Salah satu pantai indah itu adalah Pantai Panjang Bengkulu. Dari namanya, Anda pasti sudah tahu bahwa pantai ini terletak di provinsi Bengkulu.

Bengkulu merupakan provinsi yang juga memiliki garis pantai yang tegas dengan keindahan pantai nya. Pantai Panjang Bengkulu ini terdapat di kota Bengkulu, Ibukota Provinsi Bengkulu. Dinamakan demikian karena pantai ini memiliki garis pantai yang sangat panjang mencapai $7 \mathrm{~km}$ dan lebar pantai (garis pasang dan garis surut) sekitar 500 meter. Hal ini terjadi karena di sekitar pantai tidak terdapat karang sehingga saat air laut pasang membuat hamparannya menjangkau sangat jauh ke dalam pantai.

Hal ini tentu membuat pantai ini lebih indah saat surut karena hamparan pasir putihnya jadi semakin luas. Anda tidak hanya menemukan warna biru dari laut dan putih dari pantai, tapi juga hijau dari pepohonan. Kondisi pantainya yang landai, airnya yang bersih, serta hamparan pasir putihnya yang luas, merupakan daya tarik tersendiri dari obyek wisata Pantai Panjang. Dengan kondisi pantai seperti itu, pengunjung dapat mandi sepuasnya sambil menikmati semilir angin pantai yang masih bersih dan sejuk karena pantai ini jauh dari area perindustrian.

Selain itu, banyaknya pohon cemara dan pinus yang tumbuh di sekitar pantai ini juga merupakan keunikan tersendiri yang mungkin tidak dimiliki oleh pantai-pantai lainnya. Sebab, secara umum, pohon yang biasanya tumbuh di daerah pantai adalah pohon kelapa, dan ini tidak dijumpai di Pantai Panjang. Pohon cemara dan pinus ini menambah kesejukan suasana di sekitar pantai. Pantai Panjang ini juga menjadi satu-satunya pusat objek wisata terapi dengan berjogging di saat pagi atau pun sore hari di lintasannya. Pantai Panjang yang memiliki pasri putihnya yang sangat halus, tidak akan mengotori kaki Anda saat Anda berjalan-jalan.

Selain itu Anda juga bisa menikmati Pantai Panjang ini dengan jogging trek, volly pantai, bahkan jika Anda suka berselancar, pantai ini adalah tempat surfing terbaik karena ombak lautnya yang cukup besar patut untuk Anda taklukkan. Kebanyakan para pelancong yang berkunjung ke pantai ini suka menghabiskan waktu dengan berjemur di bibir pantai dan saat yang paling ditunggu adalah menikmati sunset di sore hari. Langit jingga memantulkan 
cahaya ke air yang membuat laut menjadi perak keemasan. Dan matahari yang perlahan tenggelam ke balik laut, sungguh memukau.

Pantai Panjang yang berlokasi di kawasan yang sangat strategis ini membuat tempat ini selalu di ramaikan oleh para wisatawan setiap harinya, dan untuk melengkapi objek wisata ini memberikan beberapa fasilitas publik dan juga akomodasi yang sangat lengkap, di mana jika Anda menempuh perjalanan dari pusat kota Bengkulu Anda hanya memerlukan waktu sekitar 15 dengan jarak 3 kilometer untuk bisa sampai di Pantai Panjang tersebut. Dari Kota Bengkulu, pengunjung dapat menggunakan minibus, taksi, atau mobil sewaan untuk sampai di lokasi pantai.

Di sekitar pantai, pengunjung dapat menjumpai sarana akomodasi dan fasilitas yang cukup lengkap, di antaranya adalah area parkir yang luas, hotel, restoran, kolam renang, cottage, minimarket, kios-kios penjual voucher handphone, kios-kios cendramata, dan lain-lain.

\section{Contoh Teks 2}

\section{$\underline{\text { Panorma Keindahan Bendungan Seluma }}$}

Salah satu kabupaten di Provinsi Bengkulu ini juga memiliki tempat wisata yang menarik. Selain terkenal dengan Pantai Seluma dan Tugu Bujang Gadis, disini ada destinasi yang tak kalah menarik yaitu Bendungan Seluma.

Bendungan Seluma berfungsi sebagai irigasi yang menjadi obyek wisata di Seluma, daya tarik disini berupa bendungan dengan keindahan alam yang dapat digunakan sebagai tempat rekreasi dan pemancingan.

Pemandangan alam disini sangatlah sejuk, ditambah dengan suara gemericik air akan membuat pikiran menjadi tenang. Banyak pengunjung yang berdatangan ke Bendungan Seluma untuk berfoto atau mandi. Namun, untuk mandi harus benar-benar ekstra hati-hati. Terlebih untuk anak-anak harus dengan pengawasan orang dewasa.

Di akhir pekan biasanya akan terlihat pengunjung lebih ramai di Bendungan Seluma, disini juga menjadi tempat yang menarik untuk nongkrong bersama teman-teman. Selain itu, juga ada orang yang piknik disini. Membawa bekal makan bersama keluarga atau sahabat di Bendungan Seluma sangatlah menyenangkan.

Nah, banyak juga pengemudi motor yang istirahat disini. Terutama mereka yang melaju dari Bengkulu atau hendak menuju Bengkulu. Menikmati pemandangan di sekitar Bendungan Seluma bukan hanya membuat lelah lenyap, tapi serunya jalan-jalan kesini memang tak akan terlupakan.

Tertarik untuk datang ke Bendungan Seluma?

Tempat wisata ini tak jauh dari pinggir jalan, berlokasi di desa Lubuk Kebur, kecamatan Seluma, kabupaten Seluma, Bengkulu. Di dekat Bendungan Seluma juga ada rumah makan bahkan penginapan, jadi pengunjung tak perlu khawatir jika tak sempat membawa bekal. Namun, siapkan kamera agar dapat mengabadikan pemandangan indah di Bendungan Seluma. 
Dari 2 contoh teks di atas, merupakan contoh teks sebagai bahan bacaan yang berbasis kearifan lokal siswa. Dengan teks-teks tersebut secara kognitif siswa lebih dekat dan siswa lebih mudah memahami teks sebgai bentuk dukungan gerakan literasi nasional.

\section{PEMBAHASAN}

Keberaksaraan atau literasi dapat diartikan melek teknologi, melek informasi, berpikir kritis, peka terhadap lingkungan, bahkan juga peka terhadap politik. Seorang dikatakan literat jika ia sudah bisa memahami sesuatu karena membaca informasi yang tepat dan melakukan sesuatu berdasarkan pemahamannya terhadap isi bacaan tersebut (Naibaho, 2007).

Penumbuhan literasi di sekolah dapat dilakukan melalui kegiatan rutin dan kegiatan insidental. Kegiatan tersebut dilakukan dalam tiga tahapan literasi yaitu tahap pembiasaan, pengembangan dan pembelajaran. Berikut skema pelaksanaan strategi literasi di sekolah (Kemdikbud 2017).

\section{Tiga Tahapan Pelaksanaan Literasi Sekolah}

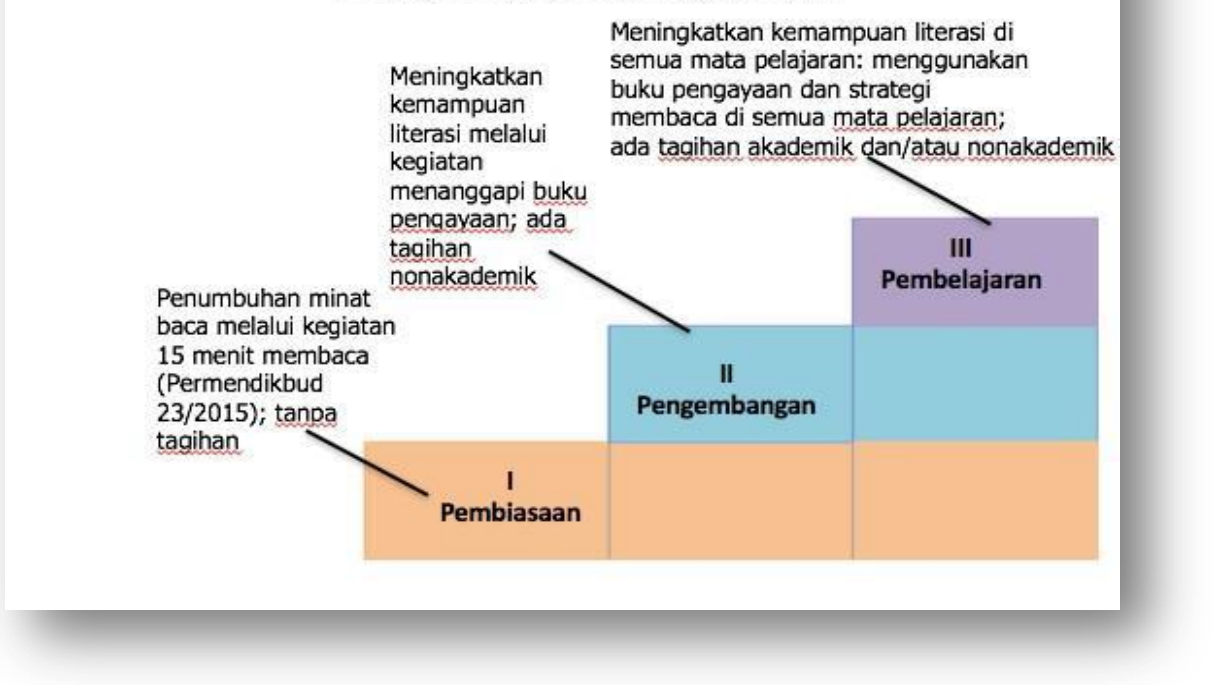

Gambar 1. Skema Tahap Pelaksanaan Lietasi Sekolah

Selama ini, gerakan literasi sekolah baru dilaksanakan pada tahap pembiasaan, yakni penumbuhan minat baca melalui kegiatan membaca 15 menit tanpa tagihan. Di beberapa sekolah telah dilakukan strategi literasi tahap kedua, yakni memberikan 
tagihan setelah siswa melakukan kegiatan membaca. Namun, kedua hal tersebut belum membuahkan hasil yang memuaskan karena pelaksanaannya sebatas pada gerakan saja. Untuk itulah, mulai tahun 2017, kemdikbud mencanangkan strategi literasi dalam pembelajaran.

Tujuan utama penggunaan strategi literasi dalam pembelajaran adalah untuk membangun pemahaman siswa, keterampilan menulis, dan keterampilan komunikasi secara menyeluruh. Tiga hal ini akan bermuara pada pengembangan karakter dan keterampilan berpikir tingkat tinggi. Selama ini berkembang pendapat bahwa literasi hanya ada dalam pembelajaran bahasa atau di kelas bahasa. Pendapat ini tentu saja tidak tepat karena literasi berkembang rimbun dalam bidang matematika, sains, ilmu sosial, teknik, seni, olahraga, kesehatan, ekonomi, agama, prakarya dll. (cf. Robb, L dalam Kemdikbud 2017).

Pembelajaran yang menerapkan strategi literasi penting untuk menumbuhkan pembaca yang baik dan kritis dalam bidang apa pun. Berdasarkan beberapa sumber, dapat disarikan tujuh karakteristik pembelajaran yang menerapkan strategi literasi yang dapat mengembangkan kemampuan metakognitif yaitu: (1) pemantauan pemahaman teks (siswa merekam pemahamannya sebelum, ketika, dan setelah membaca), (2) penggunaan berbagai moda selama pembelajaran (literasi multimoda), (3) instruksi yang jelas dan eksplisit, (4) pemanfaatan alat bantu seperti pengatur grafis dan daftar cek, (5) respon terhadap berbagai jenis pertanyaan, (6) membuat pertanyaan, (7) analisis, sintesis, dan evaluasi teks, (8) meringkas isi teks.

Indikator literasi dalam pembelajaran dapat dibagi menjadi tiga hal, yakni tahap sebelum, selama, dan setelah membaca. Pada tahap sebelum membaca, siswa dapat diminta untuk membuat tujuan membaca dan memprediksi isi bacaan. Pada tahap selama membaca siswa melakukan kegiatan mengidentifikasi informasi yang relevan, mengidentifikasi kosakata baru, kata kunci, dan/atau kata sulit dalam teks, Mengidentifikasi bagian teks yang sulit (jika ada) dan/atau membaca kembali bagian itu, memvisualisasi dan/atau think aloud, membuat inferensi, membuat pertanyaan tentang isi teks dan hal-hal yang terkait dengan topik tersebut (dapat menggunakan sumber di luar teks atau buku pengayaan), membuat keterkaitan antarteks. Pada tahap setelah membaca, siswa membuat ringkasan, mengevaluasi teks, mengubah dari satu moda ke moda yang lain, memilih, mengombinasikan, dan/atau menghasilkan teks 
multimoda untuk mengomunikasikan konsep tertentu, mengonfirmasi, merevisi, atau menolak prediksi.

Pada kegiatan literasi pembelajaran berbasis muatan lokal guru bahasa Indonesia perlu menyiapkan bahan bacaan atau teks yang sarat dengan nilai-nilai kearifan lokal. Cerita-cerita rakyat, berita, dan bacaan yang meninginspirasi dapat dipilih untuk mengembangkan karakter siswa melalui pengenalan kearifan lokal. Tahap literasi dalam pembelajaran bahasa Indonesia berbasis kearifan lokal dapat dilakukan hal-hal berikut: (1) Tahap Think-aloud siswa diharapkan dapat membunyikan secara lisan apa yang ada di dalam pikiran siswa pada saat berusaha memahami bacaan, memecahkan masalah, atau mencoba menjawab pertanyaan guru atau siswa lain. Kaitkan setiap isi bacaan dengan muatan kearifan lokal. Strategi ini dapat membantu siswa memonitor pemahamannya, berpikir tingkat tinggi, dan membentuk karakter, (2) Inferensi merupakan simpulan sementara berdasarkan informasi yang tersirat dalam teks. (3) Keterkaitan antarteks atau intertekstualitas, (4) Istilah "ringkasan" Kegiatan ini membantu siswa membentuk karakter dan berpikir tingkat tinggi, (5) Evaluasi teks, kegiatan ini membantu siswa membentuk karakter dan berpikir tingkat tinggi. (6) Moda merujuk pada bagaimana atau dengan cara apa pesan disampaikan (teks tulis, audio, visual, audiovisual, digital, kinestesik, dsb.), (7) Pengatur grafis (graphic organizers) dan (8) Konteks.

Melalui strategi literasi dalam pembelajaran bahasa Indonesia berbasis kearifan lokal siswa diharapkan dapat memahami isi teks dan mengaitkan isi teks dengan kehidupan nyata. Siswa juga dibiasakan berpikir tingkat tinggi karena selalu memprediksi di awal pembelajaran dan melakukan evaluasi di akhir pembelajaran dengan membuat simpulan. Kaitkan setiap teks yang dibaca dengan kearifan lokal yang diambil dari filosofi Jawa urip iku urup, memayu hayuning bawana, ambrasta dur hangkara, sura dira jayaningrat, lebur dening pangastuti. Jika strategi ini berhasil maka siswa dapat melakukan banyak hal yang bermanfaat bagi sesama, menjadi pribadi yang santun, jujur, bertanggung jawab, terhindar dari sikap tamak, dan dapat mengendalikan diri dari perbuatan tercela, serta tidak melakukan tindakan kekerasan pada siapa pun. Dalam hal ini, materi pembelajaran dapat memanfaatkan lingkungan belajar siswa dan sastra daerah. Misalnya lingkungan pantai, pegunungan, lingkungan pertanian dan hikayat daerah serta cerita rakyat. Dalam pembelajaran menulis teks 
deskriptif, siswa diajak memanfaatkan lingkungan siswa yaitu pesisir pantai Panjang Bengkulu.

Menurut Undang-undang Sistem Pendidikan Nasional Nomor 20 Tahun 2003 pasal 1 ayat 1, "pendidikan adalah usaha sadar dan terencana untuk mewujudkan suasana belajar dan proses pembelajaran agar peserta didik secara aktif mengembangkan potensi dirinya untuk memiliki kekuatan spritual keagamaan, pengendalian diri, kepribadian, kecerdasan, akhlak mulia, serta keterampilan yang diperlukan dirinya, masyarakat, bangsa, dan negara". Tujuan pendidikan nasional dapat dicapai dengan adanya pendidikan karakter dalam kegiatan pembelajaran pendidikan formal, semi formal, ataupun pendidikan nonformal. Pendidikan karakter terintegrasi dalam setiap mata pelajaran, tidak terkecuali pada pendidikan bahasa Indonesia. Penerapan pendidikan karakter dalam mata pelajaran bahasa Indonesia meliputi perencanaan, pelaksanaan, dan evaluasi kegiatan.

\section{Perencanaan Pendidikan Karakter dalam Pembelajaran}

Proses perencanaan pendidikan karakter meliputi, penyeleksian dan pengorganisasian butir-butir nilai yang dapat diintegrasikan dalam instrumen pembelajaran, serta penyeleksian pengalaman belajar yang layak dan bermakna dalam pembelajaran (Amri, 2011:). Perencanaan implementasi pendidikan karakter dapat menghindari kesalahan nilai atau skor yang diharapkan serta kebosanan peserta didik. Dalam melakukan perencanaan pembelajaran pendidikan karakter, pendidik diminta untuk menganalisis kondisi pembelajaran, kendala pembelajaran, sumber materi pembelajaran, karakteristik siswa, dan kompetensi yang akan dicapai.

Perencanaan pelaksanaan pembelajaran menurut Amri (2011) meliputi perencanaan pengelolaan kelas, pengorganisasian bahan, proses belajar mengajar, penggunaan sumber belajar, dan penilaian. Penilaian kegiatan pembelajaran dapat dilakukan dengan ujian tertulis, maupun melalui pengamatan langsung oleh pendidik. Dari uraian di atas, menunjukkan perencanaan pendidikan karakter dalam pembelajaran meliputi pemilihan nilai karakter yang disesuaikan dengan instrumen pembelajaran. Selain itu, nilai karakter yang dipilih juga disesuaikan dengan karakteristik siswa dan kompetensi yang akan dicapai. 


\section{Pelaksanaan Pendidikan Karakter dalam Pembelajaran}

Pendidikan karakter yang terintegrasi dalam pembelajaran merupakan pengenalan nilai-nilai dan internalisasi nilai-nilai ke dalam tingkah laku peserta didik melalui kegiatan pembelajaran (Asmani, 2011). Kegiatan pendidik saat melaksanakan pendidikan karakter dalam kegiatan pembelajaran menurut Amri, dkk. (2011) perlu menyajikan materi pembelajaran, melaksanakan metode pembelajaran, dan mendorong sisiwa untuk aktif. Penyajian materi pembelajaran dikaitkan dengan kehidupan. Pendidik dalam mengimplementasikan pendidikan karakter juga diminta membina hubungan antarpribadi. Sehingga dapat disimpulkan bahwa pelaksanaan pendidikan karakter dalam pembelajaran bertujuan untuk mengenalkan dan internalisasi nilai-nilai karakter dalam kegiatan pembelajaran. Internalisasi nilai-nilai tersebut dapat melalui metode pembelajaran yang mendorong siswa untuk aktif dan dapat mengkaitkan materi pembelajaran dengan kehidupan. Pendidik juga diminta membina hubungan antarsiswa dan pendidik.

\section{Evaluasi Pendidikan Karakter dalam Pembelajaran}

Wibowo (2012) menyatakan langkah-langkah penilaian ketercapaian implementasi pendidikan karakter meliputi penetapan indikator dari nilai-nilai yang disepakati, penyusunan instrumen penilaian, pencatatan pencapaian indikator, analisis hasil penilaian, dan tindak lanjut hasil penilaian. Hasil penilaian karakter yang telah dimiliki peserta didik digunakan pendidik dalam mengkombinasikan nilai karakter yang akan dicapai dengan kompetensi pembelajaran. Guru memperoleh informasi hasil pertumbuhan dan perkembangan sikap serta perilaku peserta didik melalui penilaian karakter peserta didik. Instrumen penilaian karakter dapat berupa lembar observasi, lembar skala sikap, portofolio, dan lembar pedoman wawancara. Penilaian karakter peserta didik tidak hanya dilakukan di dalam kelas, tetapi dapat dilakukan melalui pengamatan pergaulan peserta didik Zuriah (2011).

Penilaian pendidikan karakter menurut Kesuma (2011) bertujuan untuk mengetahui kemajuan karakter yang dimiliki peserta didik, mengetahui kekurangan dan kelebihan perencanaan pembelajaran, serta untuk mengetahui efektivitas proses pembelajaran. Penilaian karakter peserta didik dapat dilihat dari unjuk kerja siswa. 
Indikator keberhasilan pendidikan karakter meliputi: a) mengamalkan ajaran agama yang dianut sesuai dengan tahap perkembangan remaja; b) memahami kekurangan dan kelebihan diri sendiri; c) menunjukkan sikap percaya diri; d) mematuhi aturan-aturan sosial yang berlaku dalam lingkungan yang lebih luas; e) menghargai keberagaman agama, budaya, suku, ras, dan golongan sosial ekonomi dalam lingkup nasional; f) mencari dan menerapkan informasi dari lingkungan sekitar dan sumbersumber lain secara logis, kritis, dan kreatif; g) menunjukkan kemampuan berpikir logis, kritis, kreatif, dan inovatif; h) menunjukkan kemampuan belajar secara mandiri sesuai dengan potensi yang dimiliki; i) menunjukkan kemampuan menganalisis dan memecahkan masalah dalam kehidupan sehari-hari; j) mendeskripsikan gejala alam dan sosial; k) memanfaatkan lingkungan secara bertanggung jawab; 1) menerapkan nilainilai kebersamaan dalam kehidupan bermasyarakat, berbangsa, dan bernegara kesatuan Republik Indonesia; m) menghargai karya seni dan budaya sosial; n) menghargai tugas pekerjaan dan memiliki kemampuan untuk berkarya; o) menerapkan hidup bersih, sehat, bugar, aman, dan memanfaatkan waktu luang dengan baik; p) berkomunikasi dan berinteraksi secara efektif dan santun; q) memahami hak dan kewajiban diri dan orang lain dalam pergaulan di masyarakat; r) menunjukkan kegemaran membaca dan menulis naskah pendek sederhana; s) menunjukkan keterampilan menyimak, berbicara, membaca, dan menulis dalam bahasa Indonesia dan bahasa Inggris sederhana; t) menguasai pengetahuan yang diperlukan untuk mengikuti pendidikan menengah; u) memiliki jiwa kewirausahaan (Asmani, 2011). Sehingga disimpulkan bahwa penilaian pendidikan karakter dilakukan untuk mengetahui ketercapaian indikator-indikator karakter yang dipilih. Selain itu tujuan dari penilaian ketercapaian pendidikan karakter, juga dapat digunakan sebagai acuan penilaian ketercapaian pembelajaran.

\section{SIMPULAN}

Pelaksanaan pendidikan karakter dalam pembelajaran bertujuan untuk mengenalkan dan internalisasi nilai-nilai karakter dalam kegiatan pembelajaran. Internalisasi nilai-nilai tersebut dapat melalui metode pembelajaran yang mendorong siswa untuk aktif dan dapat mengkaitkan materi pembelajaran dengan kehidupan. Pendidik juga diminta membina hubungan antarsiswa dan pendidik. Dalam pembelajaran bahasa Indonesia, strategi litarasi perlu dilakukan dengan berbagai cara. 
Salah satu cara yang dapat dilakukan adalah dengan menerapkan strategi literasi dalam pembelajaran bahasa Indonesia berbasis kearifan lokal. Dalam hal ini, materi pembelajaran dapat memanfaatkan lingkungan belajar siswa dan sastra daerah. Misalnya lingkungan pantai, pegunungan, lingkungan pertanian dan hikayat daerah serta cerita rakyat. Dalam pembelajaran menulis teks deskriptif, siswa diajak memanfaatkan lingkungan siswa yaitu pesisir pantai Panjang Bengkulu.

\section{DAFTAR PUSTAKA}

Amri, Sofan. (2011). Implementasi Pendidikan Karakter dalam Pembelajaran. Jakarta: PT. Prestasi Pustakaraya.

Asmani, Jamal Ma'mur. (2011). Buku Panduan Internalisasi Pendidikan Karakter di Sekolah. Yogyakarta: Diva Press.

Kemdikbud. (2017). Strategi Literasi dalam Pembelajaran di sekolah Menengah Pertama: Materi Penyegaran Instruktur Kurikulum 2013.

Kesuma, Dharma, (2011). Pendidikan Karakter Kajian Teori dan Praktik di Sekolah. Bandung: Remaja Rosdakarya.

Naibaho, Kalarensi. (2007). Menciptakan Generasi Literat Melalui Perpustakaan. Diunduh tanggal 5 Mei 2017.

Peraturan Menteri Pendidikan dan Kebudayaan Nomor 23 Tahun 2015. Pengembangan Gerakan Literasi. Jakarta: Kemendikbud.

Sugiyono. (2010). Metode Penelitian Pendidikan Pendekatan Kuantitatif, Kualitatif, dan $R \& D$. Bandung: Alfabeta.

Undang-Undang RI No. 20 Tahun 2003. Sistem Pendidikan Nasional. Jakarta: Lembaga Informasi Nasional.

Wibowo, Agus. (2012). Pendidikan Karakter: Strategi Membangun Karakter Bangsa Berperadaban. Yogyakarta: Pustaka Pelajar.

Zuriah, Nurul. (2011). Pendidikan Moral dan Budi Pekerti Dalam Prespektif Perubahan. Jakarta: Bumi Aksara. 